\title{
Country Contact Tightness Influence Analysis Using Indirect Effects
}

\author{
Miaozhi Fang, Xun Lu* \\ School of Computer Science \& Technology, Soochow University, Suzhou, China \\ Email: ${ }^{*}$ luxun@suda.edu.cn
}

Received 13 September 2014; revised 15 October 2014; accepted 8 November 2014

Copyright (C) 2014 by authors and Scientific Research Publishing Inc.

This work is licensed under the Creative Commons Attribution International License (CC BY).

http://creativecommons.org/licenses/by/4.0/

(c) (i) Open Access

\begin{abstract}
Contact tightness is significant in today's diverse blend of modern society. We can see it on almost every corner of modern society, from developing and carrying out large external activities of the country's foreign policy, to small affairs like business marketing and interpersonal communication. This paper aims to study the China's economic ties with the world's major political and economic tightness, which can help us make a comprehensive measure of China's international influence. In addition, China's strengths and weaknesses can be measured more accurately and exhaustively.
\end{abstract}

\section{Keywords}

The Bilateral Trade Volume, Indirect Influence, Economic Influence, Political Influence

\section{Introduction}

Currently, some of the views for China's international status are emphasis on the total amount of China's GDP, as well as some pessimistic view of the status quo view of China, the lack of quality of China's economic development and sustainability. With the China into WTO, China's economy is melting into the world economy. In order to maximize the real reflects of China's international status, we now select the "economic ties tightness" [1] and "close political ties" [2] as the inquiry is currently China's economic clout and political influence of the two indicators. Topics in this article as "the analysis based on indirect effects of China's influence”, is as used herein, economic and political influence to a brief description.

\section{Theory Research}

For the treatment of indirect impacts of this paper, we can use the indirect impact [3] of economic ties to make a

"Corresponding author. 
statement in here.

\subsection{Calculation Method}

We can use the following 6 equations to evaluate the influence of the countries.

$$
\begin{gathered}
T_{X Y}=R^{0} * W_{X Y}+R^{1} * W_{1}+R^{2} * W_{2} \\
W_{1}=\sum W_{X M Y} \\
W_{2}=\sum W_{X M N Y} \\
W_{X M Y}=W_{X M}+W_{M Y} \\
W_{X M N Y}=W_{X M}+W_{M N}+W_{N Y} \\
R=\frac{1}{2}, R \in(0,1)
\end{gathered}
$$

where $T_{X Y}$ is the contact tightness between country $X$ with country $Y, W_{X Y}$ is the direct impact between countries $X$ with country $Y . W_{1}$ is the sum of all the first indirect influences between countries $X$ with country $Y, W_{X M Y}$ is the first indirect influences between countries $X$ with country $Y$. In Equation (2), $M$ is a country connect country $X$ with country $Y, M$ is variable. $W_{2}$ is the sum of all the second indirect influences between countries $X$ with country $Y, W_{X M N Y}$ is the second indirect influences between countries $X$ with country $Y$. In Equation (3), $M$ is a country connect country $X$ with country $N, N$ is a country connect country $M$ with country $Y, M, N$ are variable. $R$ is the function weight whose ranges from 0 to 1 . In this study, the value of $R$ is $1 / 2$.

\subsection{Examples}

For example, country $A$, country $B$ and country $C$ all have trade with each other. The bilateral trade [4] between $A$ and $C$ is 10 . The bilateral trade between $A$ and $B$ is 8 , while the bilateral trade between $B$ and $C$ is 6 . The direct trade between the country $A$ and the country $C$ is called the direct impact, which can be directly included in the influence.

The impact of state $A$ to state $C$ which is through the state $B$ is known as the indirect effects [5]. Since country $B$ is the only connected country between country $A$ and country $C$, this kind of indirect influence is called the first indirect influence. Its calculation method is $W_{1}=R^{1} * W_{A B C}=(1 / 2) *\left(W_{A B}+W_{B C}\right)=7$. If there exist two indirect influence nation, which is called the country $B$ and the country $D$, between the country $A$ and country $C$, then we call them the second indirect influence. Its calculation method is

$W_{2}=R^{2} * W_{A B D C}=(1 / 2) *\left(W_{A B}+W_{B D}+W_{D C}\right)$. Then the tightness of economic ties between country $A$ and country $C$ is:

$$
T_{A C}=R^{0} * W_{A C}+R^{1} * W_{1}+R^{2} W_{2}=W_{A C}+(1 / 2) * W_{A B C}=W_{A C}+(1 / 2) *\left(W_{A B}+W_{B C}\right)=10+7=17
$$

This research covers the analysis of 14 countries, including: China, US, Japan, Germany, France, Britain, Italy, Canada, Russia, Argentina, Australia, Brazil, India and South Africa.

Taking the research conditions and technical conditions into account, the amount of calculation will increase sharply in index form when the levels of indirect influence's calculation also rise. So we only calculate to the second indirect influence.

\section{The Analysis Based on Indirect Effects of China's Economic Influence}

When it comes to the measure of economic powers in the world, it is difficult to make scholars hold the same opinion.

\subsection{The Common Standard}

The most common standard for world economic powers is mainly to measure from the total economy [6] and international economic ties [7]. First, there must be a huge amount of national economy. In other words, the GDP of a country must account for more than $5 \%$. Second, there must be close international economic ties. 
That is the total foreign trade accounting for more than $5 \%$ of global trade [8]. The domestic currency is an international reserve currency [9], and accounts for over 5\% of global reserves. Economic aggregates [10] (mainly GDP [11]) reflects the overall size of a country's economy, and the international economic ties may reflect the degree of openness of a country's economy.

In 2013, global GDP reached 73.98 trillion US dollars [12]. And the US GDP in 2013 was \$16.7997 trillion, which ranked first; China’s GDP was \$9.1814 trillion at that time, second only to the USA. China’s GDP accounted for about $12.4 \%$ of the world GDP.

In 2013, China's share of global trade in goods rose to $11.05 \%$, which was the first time to rank first in the world. Except that the RMB has not yet become an international reserve currency, two indicators are far beyond the standards of the world's largest economy. Some countries have used RMB as a reserve currency for several years, but "still unwilling to speak out". It can be seen that China has already been one of a world largest economy [13].

\subsection{The Improved Method}

Previous data has shown that the total trade in goods [14] of China in 2013 has become the world's first. The usual practice is to use total foreign trade as a measure of international economic ties. China's international economic ties have also been the world first according to the most commonly used standard.

However, without the consideration of other economic ties between countries, the most common means to measure the international economic links only takes the national total foreign trade volume, which is a simple addition of the bilateral trade volume, into consideration. And to make it easy to understand, this article will explain the issue with economic impact.

There is an example to illustrate the indirect economic impact. Suppose, there is a trade between country $A$ and country $B$, and it is the same with country $B$ and country $C$. Although country $C$ itself doesn't do business with country $A$ directly, it imports goods from country $B$ which manufactures the goods with the materials exported by country $A$. As a result, there still exists an economic link between country $A$ and country $C$, and this is so-called indirect economic impact.

This article will do some research about the bilateral trade in 14 major countries and take the opportunity to explore whether China reaches the first place in international economic clout.

The following figure shows the final analysis of 2009-2013 national economic impact.

\subsection{Data Analysis}

As showed in Figure 1, American economic influence is highest, China is the second. China's foreign trade data [15] indicated that total foreign trade in 2012 officially surpassed the United States, and the gap continues to widen in the year of 2013, from \$48.15 billion in 2012 to \$3142.9 in 2013. These raw data shown that the influence of China's economy seemed to surpass the United States form 2012 and the gap is wide in 2013. However, these were only the false appearance of raw data. The real economic impacts by no means consider only total bilateral trade and total trade, but also you should take the indirect ties all over the world. Thus, after considering the indirect economic ties we can find that China's economic influence has not surpassed the USA in the last five years. From 2009 to 2013, the average economic influence of US and China were 11.26 and 10.77, and the gap is large. At the same time, the US exports are of high quality. Therefore, the gap of economic influence between China and US remains relatively great. In the final result of the study about economic impact, 14 countries are divided into three echelons. The first tier are: the USA, China; The second tier are: Japan, Germany, Canada; And the third tier is: France, Britain, Italy, Russia, Australia, Brazil, India, South Africa and Argentina. Among these countries, the sum of developing countries' economic influence is close to $40 \%$. We can see that the status of developing countries has been upgraded while the traditional Western forces are still in a leading position.

We can make a speculation based on research results that with the end of China's demographic dividend, the economic uncertainty will increase. In 2013, the internal differentiation of developed countries and developing countries increased, for instance, the United States is stronger, Europe and Japan is weaker. With the continuing promotion of the US shale gas revolution [16] and manufacturing revival plan [17], US economic growth will continue. Speculated that the peak of the economic influence between China and US will be at around $11.5 \%$. This peak can be reached in the United States in 2025, in the same period, the economic influence of China 
should be around $11.2 \%$, and the Chinese economic influence will be reached to the same peak around 2050 and be equal to the United States. Of course, the rise of each country are accompanied by a comprehensive range of game, the way of China's revival is still difficult.

\section{The Analysis Based on Indirect Effects of China's Political Influence}

Figure 2 is a screenshot of political influence about 14 countries.

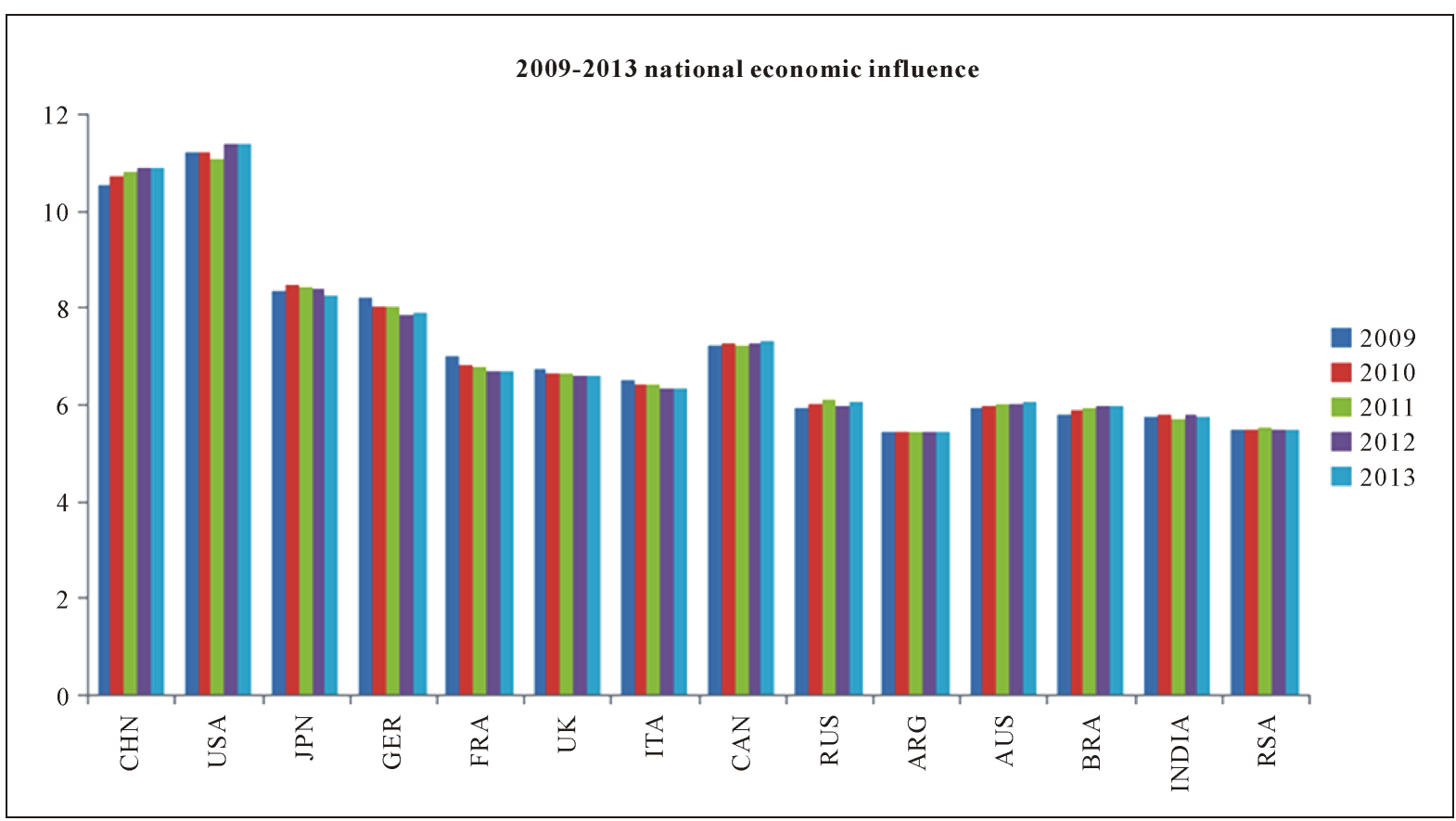

Figure 1. 2009-2013 national economic influence about 14 countries.

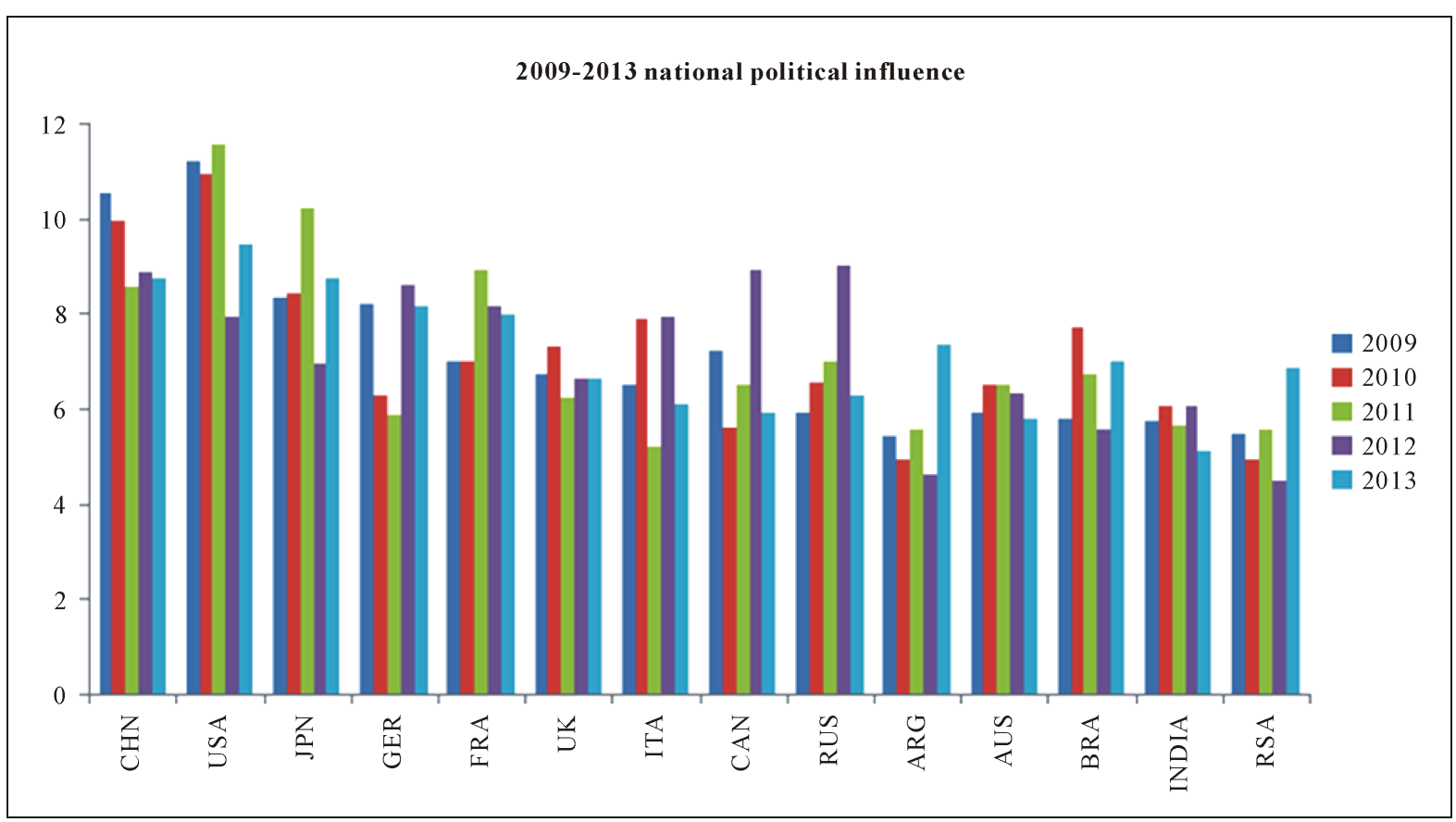

Figure 2. 2009-2013 national economic influence about 14 countries. 


\subsection{Basis for Data Analysis}

Data processing and analysis of political influence are the first order for the new heads of the two states to visit the country, the number of joint military exercises this year, whether to establish diplomatic relations [18] at ambassadorial level as well as the number of over the provincial officials' and less than heads of state's mutual visits.

\subsection{Data Analysis}

According to the screenshot, we can see that the fluctuation of the political influence is relatively large, in which the following countries can be ranked in the first tier of political influence, they are: the United States, China, and Japan. The fluctuations of the remaining country is large, for which we won't do echelon distribution.

From the analysis results of comprehensive economic clout and political influence, we can see that, the gap between China's political influence and economic clout is the greater than the US gap, although China's economic strength has surpassed Japan, but did not open a clear gap with Japan in the political influence, and has showed a downward trend the last five years. Thus it reflects that the China's ability of foreign relations still lacks,

In this regard, China should pay attention to the country's image and culture, and strive to enhance the soft power. At the same time, China should strengthen diplomatic construction to create a stable and peaceful external environment for economic development.

\section{Conclusion}

After decades of rapid development, China's total external trade in goods, has become the first in the world in 2013, but China's real economic impact is still behind the United States. Gap between China and the US of political influence is greater than the economic influence gap between China and the US, and thus we can see that the United States' first place in the world still cannot be shaken in the short term. But compared to other countries, China's overall influence advantages have been relatively obvious.

\section{Acknowledgements}

Miaozhi Fang, student ID Number: 1227402013, currently is an undergraduate student of Computer Science and Technology School of Soochow University. This work was directed by Xun Lu.

\section{References}

[1] Guichet, D.L., Yoshinobu, D. and Caputo, A.A. (2002) Effect of Splinting and Interproximal Contact Tightness on Load Transfer by Implant Restorations. The Journal of Prosthetic Dentistry, 87, 528-535. http://dx.doi.org/10.1067/mpr.2002.124589

[2] Samoff, J. (2003) Institutionalizing International Influence. Safundi: The Journal of South African and American Comparative Studies, 4, 1-35. http://dx.doi.org/10.1080/17533170300404104

[3] Abeysinghe, T. (2001) Estimation of Direct and Indirect Impact of Oil Price on Growth. Economics Letters, 73, 147153. http://dx.doi.org/10.1016/S0165-1765(01)00476-1

[4] Deardorff, A. (1998) Determinants of Bilateral Trade: Does Gravity Work in a Neoclassical World? The Regionalization of the World Economy. University of Chicago Press, Chicago, 7-32.

[5] Sobel, M.E. (1982) Asymptotic Confidence Intervals for Indirect Effects in Structural Equation Models. Sociological Methodology, 13, 290-312. http://dx.doi.org/10.2307/270723

[6] Guttmann, P.M. (1977) The Subterranean Economy. Financial Analysts Journal, 33, 26-34. http://dx.doi.org/10.2469/faj.v33.n6.26

[7] Gilpin, R. (2011) Global Political Economy: Understanding the International Economic Order. Princeton University Press, Princeton.

[8] (1998) Global Trade Analysis: Modeling and Applications. Cambridge University Press, Cambridge.

[9] Chinn, M. and Frankel, J.A. (2007) Will the Euro Eventually Surpass the Dollar as Leading International Reserve Currency? G7 Current Account Imbalances: Sustainability and Adjustment. University of Chicago Press, Chicago, 283338. 
[10] Downs, A. (1957) An Economic Theory of Democracy. Harper Press, New York.

[11] Gleditsch, K.S. (2002) Expanded Trade and GDP Data. Journal of Conflict Resolution, 46, 712-724. http://dx.doi.org/10.1177/0022002702046005006

[12] Davidson, O., Bosch, P., Dave, R., et al. (2007) Mitigation of Climate Change. Cambridge University Press, Cambridge.

[13] Gilpin, R. and Gilpin, J.M. (2000) The Challenge of Global Capitalism: The World Economy in the 21st Century. Princeton University Press, Princeton.

[14] Markusen, J.R., Venables, A.J., Konan, D.E. and Zhang, K.H. (1996) A Unified Treatment of Horizontal Direct Investment, Vertical Direct Investment, and the Pattern of Trade in Goods and Services. National Bureau of Economic Research Working Paper No. 5696. http://dx.doi.org/10.3386/w5696

[15] Goldstein, M. and Khan, M.S. (1985) Income and Price Effects in Foreign Trade. Handbook of International Economics, 2, 1041-1105. http://dx.doi.org/10.1016/S1573-4404(85)02011-1

[16] Stevens, P. (2010) The "Shale Gas Revolution": Hype and Reality. Chatham House, London.

[17] Beale, C.L. (1975) The Revival of Population Growth in Nonmetropolitan America. Economic Research Service, US Department of Agriculture, Washington DC.

[18] Logan, R.W. (1941) The Diplomatic Relations of the United States with Haiti, 1776-1891. The University of North Carolina Press, Chapel Hill. 
Scientific Research Publishing (SCIRP) is one of the largest Open Access journal publishers. It is currently publishing more than 200 open access, online, peer-reviewed journals covering a wide range of academic disciplines. SCIRP serves the worldwide academic communities and contributes to the progress and application of science with its publication.

Other selected journals from SCIRP are listed as below. Submit your manuscript to us via either submit@scirp.org or Online Submission Portal.
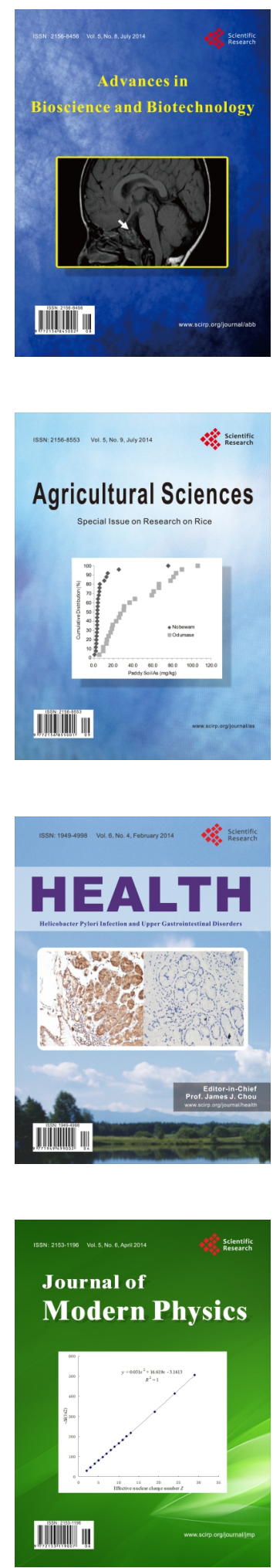
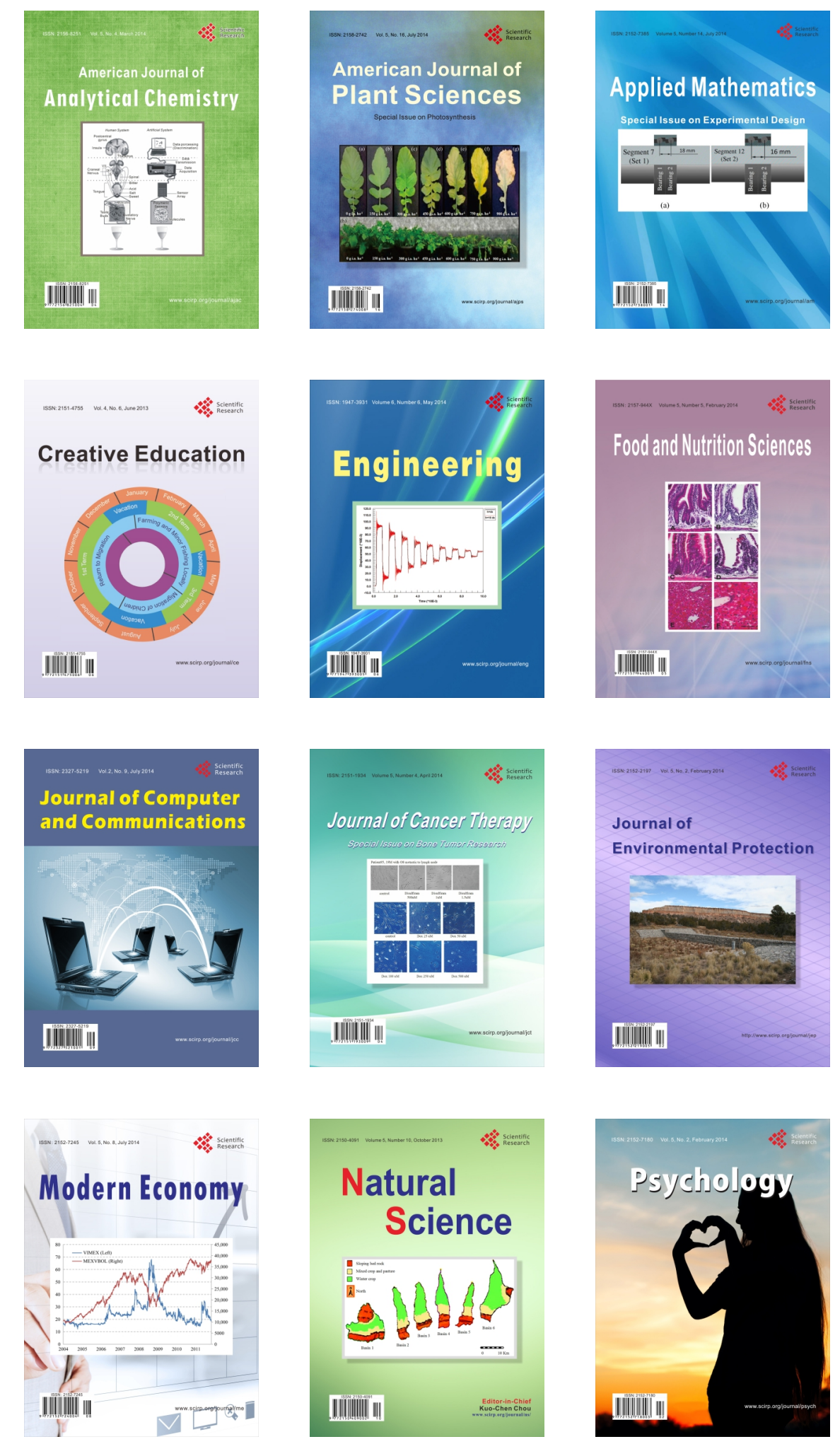